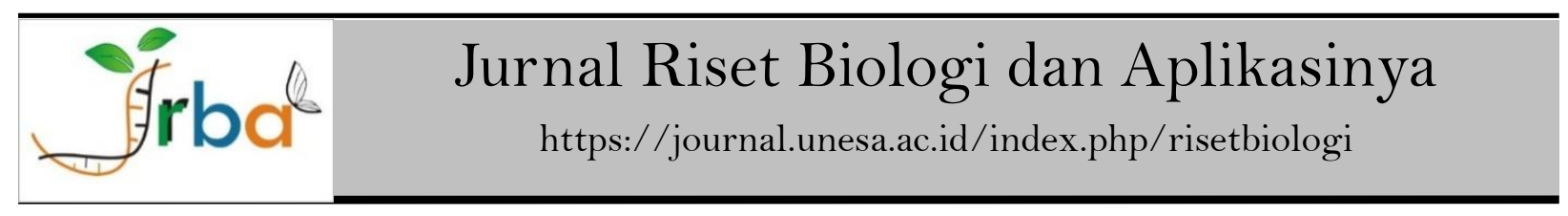

\title{
Diversity of Butterflies (Hexapoda: Lepidoptera: Rhopalocera) Around Campus 4 of Universitas Ahmad Dahlan
}

\author{
Ichsan Luqmana Indra Putra ${ }^{1^{*}}$, Haris Setiawan ${ }^{2}$, Tasya Aulia Putri ${ }^{3}$ \\ ${ }^{1}$ Laboratory of Ecology and Systematics, Faculty of Applied Science and Technology, Ahmad Dahlan University; \\ ${ }^{2}$ Laboratory of Animal Structure and Physiology, Faculty of Applied Science and Technology, Ahmad Dahlan University; \\ ${ }^{3}$ Biology Department, Faculty of Applied Science and Technology, Ahmad Dahlan University \\ Jln. Ring Road Selatan, Tamanan, Banguntapan, Bantul, Yogyakarta 55191, Indonesia \\ *Corresponding Author: \\ e-mail: ichsan.luqmana@bio.uad.ac.id
}

\section{Article History \\ Received : 24 May 2021 \\ Revised : 20 July 2021 \\ Approved : 2 September 2021 \\ Published : 30 September 2021}

\section{Keywords}

Butterfly; diversity; dominance;

Rhopalocera; Shannon Wiener.

\begin{abstract}
The conversion of land functions can result in a decrease of environmental quality, which can reduce the diversity of butterflies. This study aimed to determine the diversity level and to find the most abundant and less abundant butterfly species around campus 4 UAD. The sampling was done at campus area, vacant land, rice fields and housing sites. Each of these sites had 2 plots and consisted of 5 subplots, respectively. Sampling was carried out four times, which was done in the morning at $08.00-11.00$ and in the afternoon at $15.00-17.00$. Butterflies caught using a sweep net. The data were analyzed by inferential analysis, namely Pearson correlation test. The calculation of the diversity level of butterflies was carried out by calculating the importance value index, the diversity Shannon-Wiener index, and the Simpson dominance index. The results showed that the diversity level of Shannon Wiener index of butterflies around the campus 4 UAD showed a low level (0.67). The species of butterflies found around campus 4 UAD were Acraea violae, Aphrissa statira, Appias libythea, Appias olferna, Catopsilia pyranthe, Catopsilia Scylla, Danaus Chrysippus, Elymnias hypermnestra, Junonia almana, and Junonia atlites. The most abundant butterfly was $C$. pyranthe with 125 individuals whereas the least abundant was $A$. libythea with 1 individual. This suggested that the ecosystem around campus 4 UAD is disturbed category; causing instability of the diversity that exists, including butterflies.
\end{abstract}

How to cite: Putra, I.L.I., Setiawan, H., \& Putri, T.A. (2021). Diversity of Butterfly Species (Hexapoda: Lepidoptera: Rhopalocera) Around Universitas Ahmad Dahlan Campus 4. Jurnal Riset Biologi dan Aplikasinya, 3 (2): 54-62. DOI: 10.26740/jrba.v3n2.p54-62.

\section{INTRODUCTION}

Changes in land functions that are increasing by humans, such as building homes and places to do business, will cause the available land decrease continuously (Pewista \& Harini, 2013). The longer of functional changes in the ecosystem, the faster decreasing in environmental quality which will disturb the balance of the ecosystem (Thom \& Seidl, 2016). This was added by (Triyogo et al., 2016), another problem of land use change that can arise is a decrease in the level of diversity. The decline in diversity can occur because the land, which was originally a habitat for living things, has changed its function into student boarding houses and food stalls. Some of the organisms can be affected by the conversion of land use, for example butterflies (Hexapoda: Lepidoptera: Rhopalocera).

Butterflies are one of the insects that must be protected from extinction and population decline (Sea et al., 2012). Butterflies have important values for humans and the environment, such as maintaining the balance of ecosystems and 
enriching biodiversity (Susilawati, 2010). According to (Septiana et al., 2019), the existence of butterflies in nature has various important functions, namely as flower pollinators, ecosystem components, and bio-indicators. According to Diana et al., (2015), land use change in ecosystem, habitat and resources can affect the level of diversity of butterflies in these habitats. This is made clear by Diana et al., (2015), which states that butterflies are insects that can respond to environmental changes, such as vegetation degradation and pollutions.

Research on butterfly diversity in Pinang Masak Campus, Jambi University found 143 individuals from 5 butterfly families, namely Papilionidae, Pieridae, Nymphalidae, Lycaenidae and Hesperiidae (Dewi et al., 2016). The species of butterflies that were found in abundance were Junonia orithya followed by Acraea terpsicore and Eurema hecabe. Because of habitat alternation in around campus 4 of Universitas Ahmad Dahlan (UAD), Yogyakarta due to campus development, it can affect the diversity and abundance of butterflies in this area. Given the importance of the ecological function of butterflies in nature, this research is important to do to provide a database of butterflies around campus 4 UAD in a sustainable conservation effort. The purpose of this study was to determine the diversity level of butterfly species and to find the dominant and less dominant butterfly species around the campus area 4 Yogyakarta.

\section{MATERIALS AND METHODS}

\section{Location Determinations and Sampling Points}

The research locations were carried out at the area of Campus 4 Universitas Ahmad Dahlan (UAD). The research locations consisted of campus areas, vacant land, housing, and rice fields. Each area has 2 plots with a size of each plot measuring $750 \mathrm{~m}^{2}$. Each plot consisted of 5 subplots with a size of $15 \mathrm{~m} \mathrm{x} 10 \mathrm{~m}$.

\section{Butterfly Sampling and Abiotic Factors Measurement}

Sampling was carried out four times. The time interval for sampling was once a week. Butterfly samples were taken in the morning from 08.00 $11.00 \mathrm{am}$ and continued in the afternoon at 03.00 $05.00 \mathrm{pm}$. The selection of data collection time was based on the active time of most butterfly species. Butterflies were caught using a sweepnet. The captured butterflies were put into papilot paper so that the butterfly wings are not damaged.
Butterflies were killed by pressing their thoracic part in papillot paper.

The dead butterfly was placed on the sterofoam and pinned in the thorax using a pin and its wings were spread out using papillot paper. Furthermore, the butterflies were dried using a cardboard box given an incandescent lamp of 10 watts for 2 days. After that, a species label and a description of where it was found on each specimen was given.

Measurements of abiotic factors in the field were air temperature, air humidity, wind speed, and light intensity. Air temperature and humidity was measured using a thermo-hygrometer. Wind speed was measured using the anemometer Benetech. Light intensity was measured using lux meter smart sensor.

\section{Host Plant Observation}

The host plant of butterfly's observation was done by observing the adult butterflies. Flowering plants visited by butterflies were recorded. The literatures were also used to confirm the host plant of the butterflies in the sampling areas.

\section{Butterfly Identification}

The dried butterflies were then identified based on the characters of the thorax, abdomen, and ornaments on the dorsal and ventral wings. Identification was carried out by comparing the morphological characteristics of the samples with the identification book (Ruslan dkk., 2020; Resasco, 2009).

\section{Data Analysis}

Data analysis of abundance of butterflies and abiotic factors in this study were analyzed used normality test and Pearson correlation test. The calculation of the diversity level of butterflies was done by calculating the importance value index and diversity index using the formula Shannon-Wiener and the Simpson dominance index with the formula (Help et al., 1998):

\section{Importance Value Index}

$$
\begin{aligned}
& \text { Density }=\frac{\text { density a species }}{\text { Total species density }} \\
& \text { Relative density }=\frac{\text { density a species }}{\text { Total species density }} \times 100 \% \\
& \text { Frequency }=\frac{\text { Frequency } \text { a species }}{\text { Total species frequency }} \\
& \text { Relative frequency }=\frac{\text { Frequency a species }}{\text { Total species frequency }} \times 100 \% \\
& \text { Importance value index }=\text { Relative density }+ \text { Relative } \\
& \text { frequency }
\end{aligned}
$$




\section{Shannon-Wiener Diversity Index (H')}

$$
\begin{aligned}
& \mathrm{H}^{\prime}=-\sum p i \ln p i \\
& p i=\frac{n i}{N}
\end{aligned}
$$

Note:

$\mathrm{H}^{\prime}$ : Shannon-Wiener diversity index

$p i=\mathrm{ni} / \mathrm{N}$

ni: number of species individual at-i

$\mathrm{N}$ : Total amount of species individual

Shannon-Wiener diversity index criteria:

$\mathrm{H}^{\prime}<2=$ Low diversity

$2<\mathrm{H}^{\prime}<3=$ Medium diversity

$\mathrm{H}^{\prime}<3=$ High diversity (Lestari et al., 2018).

\section{Dominance Index (D)}

Butterfly species dominance was counted using Simpson dominance index (D):

$$
\mathrm{D}=\frac{n i}{N} \times 100 \%
$$

Note:

D: Dominance index

ni: Individual species amount

N: Total species amount (Lestari et al., 2018)

\section{RESULTS AND DISCUSSION}

\section{Butterfly Diversity Index (Lepidoptera: Rhopalocera) Around Campus 4 UAD}

Based on the results of the research that has been done, the Shannon-Winner diversity index value found around the campus $4 \mathrm{UAD}$ area was 0.67. The results obtained in this study obtained the index value of butterfly species diversity around the campus $4 \mathrm{UAD}$, which was low $\left(\mathrm{H}^{\prime}<1\right)$. The results showed that the highest IVI value was found in species C. pyranthe of 80.11 with a density of 125 individuals. While the lowest IVI value was found in species $A$. libythea of 1.23 with a density of 1 (Table 1).

The important value index shows the species that dominate the research location (Hidayat, 2018). This was supported by the statement from Mawazin \& Subiakto (2013), that the INP value is used to determine the dominance of a species in a community. Saharjo \& Gago (2011) added that the greater the IVI value of a species, the greater the level of control over the community, and vice versa. The results obtained in this study obtained the index value of butterfly species diversity around the area of Campus $4 \mathrm{UAD}$, which was low $\left(\mathrm{H}^{\prime}<1\right)$. The low diversity index value indicated that there are factors that influence the existence and abundance of butterfly species around Campus 4 of UAD

\begin{tabular}{|c|c|c|c|c|c|c|c|c|c|c|c|}
\hline No & Species & $\begin{array}{l}\text { Species } \\
\text { amount }\end{array}$ & $\mathrm{Pi}$ & $\begin{array}{c}\mathrm{Log} \\
\mathrm{Pi} \\
\end{array}$ & $\begin{array}{c}\text { pi log } \\
\text { pi }\end{array}$ & $\mathrm{D}$ & DR & Dom & $\mathrm{F}$ & $\mathrm{FR}$ & INP \\
\hline 1 & $\begin{array}{l}\text { Acraea } \\
\text { violae }\end{array}$ & 25 & 0.10 & -1.01 & -0.10 & 25 & 9.80 & 0.10 & 19 & 15.97 & 25.77 \\
\hline 2 & $\begin{array}{l}\text { Aphrissa } \\
\text { statira }\end{array}$ & 16 & 0.06 & -1.20 & -0.08 & 16 & 6.27 & 0.06 & 9 & 7.56 & 13.84 \\
\hline 3 & $\begin{array}{l}\text { Appias } \\
\text { libythea }\end{array}$ & 1 & 0.004 & -2.41 & -0.01 & 1 & 0.39 & 0.00 & 1 & 0.84 & 1.23 \\
\hline 4 & $\begin{array}{l}\text { Appias } \\
\text { olferna }\end{array}$ & 16 & 0.06 & -1.20 & -0.08 & 16 & 6.27 & 0.06 & 11 & 9.24 & 15.52 \\
\hline 5 & $\begin{array}{l}\text { Catopsilia } \\
\text { pyranthe }\end{array}$ & 125 & 0.49 & -0.31 & -0.15 & 125 & 49.02 & 0.49 & 37 & 31.09 & 80.11 \\
\hline 6 & $\begin{array}{l}\text { Catopsilia } \\
\text { Scylla }\end{array}$ & 2 & 0.01 & -2.11 & -0.02 & 2 & 0.78 & 0.01 & 1 & 0.84 & 1.62 \\
\hline 7 & $\begin{array}{l}\text { Danaus } \\
\text { chrysippus }\end{array}$ & 55 & 0.22 & -0.67 & -0.14 & 55 & 21.57 & 0.22 & 31 & 26.05 & 47.62 \\
\hline 8 & $\begin{array}{l}\text { Elymnias } \\
\text { hypermnes } \\
\text { tra }\end{array}$ & 4 & 0.02 & -1.80 & -0.03 & 4 & 1.57 & 0.02 & 3 & 2.52 & 4.09 \\
\hline 9 & $\begin{array}{l}\text { Junonia } \\
\text { almana }\end{array}$ & 9 & 0.04 & -1.45 & -0.05 & 9 & 3.53 & 0.04 & 5 & 4.20 & 7.73 \\
\hline 10 & $\begin{array}{l}\text { Junonia } \\
\text { atlites }\end{array}$ & 2 & 0.01 & -2.11 & -0.02 & 2 & 0.78 & 0.01 & 2 & 1.68 & 2.46 \\
\hline & Total & 255 & 1.00 & -14.26 & -0.67 & 255 & 100.00 & 1.00 & 119 & 100.00 & 200.00 \\
\hline
\end{tabular}
Yogyakarta.

Table 1. Species diversity index and INP of butterfly around campus 4 UAD Yogyakarta

Note: Pi: species amount at-i; D: density; DR: relative density; Dom: dominance; F: frequency, FR: Relative frequency; INP: important value index 
This factor is in the form of changing the function of the existing green area. This was consistent with research from Koh \& Sodhi (2004), where the diversity and abundance of butterflies in areas that have changed their function is lower than in natural ecosystems.

The change in function conversion is due to massive changes that have occurred around the campus area 4, resulting in reduced green open land and conversion of other land functions into boarding houses or food stalls. According to research by Fattorini (2011), several types of insects such as butterflies and beetles have become extinct due to land conversion and loss of green open space. The reduction in green open land available, of course, can have a direct effect on the life of butterflies (Diana et al., 2015), both in terms of flying for food and the opportunity to find a partner, or choosing the location of oviposition (Diana et al., 2015). The important value index shows the species that dominate the research location (Hidayat, 2018). This was supported by the statement from Mawazin \& Subiakto (2013), that the INP value is used to determine the dominance of a species in a community. Saharjo \& Gago (2011) added that the greater the IVI value of a species, the greater the level of control over the community, and vice versa. The results obtained in this study obtained the index value of butterfly species diversity around the area of Campus $4 \mathrm{UAD}$, which was low $\left(\mathrm{H}^{\prime}<1\right)$. The low diversity index value indicated that there are factors that influence the existence and abundance of butterfly species around Campus 4 of UAD Yogyakarta. This factor is in the form of changing the function of the existing green area. This was consistent with research from Koh \& Sodhi (2004), where the diversity and abundance of butterflies in areas that have changed their function is lower than in natural ecosystems.

The change in function conversion is due to massive changes that have occurred around the campus area 4, resulting in reduced green open land and conversion of other land functions into boarding houses or food stalls. According to research by Fattorini (2011), several types of insects such as butterflies and beetles have become extinct due to land conversion and loss of green open space. The reduction in green open land available, of course, can have a direct effect on the life of butterflies (Diana et al., 2015), both in terms of flying for food and the opportunity to find a partner, or choosing the location of oviposition (Diana et al., 2015).
Apart from the direct effect, changes in land use change also have an indirect effect on butterfly life. The indirect effect of land use change on butterfly life is the reduction in vegetation as butterfly food (Mogan et al., 2018). This is consistent with research from Ngatimin et al., (2017), which states that the diversity of butterfly species in Bantimurung-Bulusaraung National Park has low index values in various habitats that are thought to have occurred for forest function conversion and illegal hunting. Another study from Koh \& Sodhi (2004), found that protected areas have a higher diversity of butterfly species than areas that have undergone land conversion. In addition, Lestari et al (2015), butterflies face the threat of extinction caused by the conversion of land functions from natural ecosystems to agricultural or residential ecosystems. According to research from (Setiawan et al., 2018), getting the results of natural ecosystems with conditions that are still maintained or habitats that have not been degraded, especially in conservation areas, have a higher level of diversity and abundance of butterflies than ecosystems that have changed function, either the threat of land conversion into agricultural land (Setiawan et al., 2018), plantation areas (Basuki, 2019), or into residential land (Bahar et al., 2016).

In addition to reducing green open space, land use conversion to settlement can also affect the diversity of butterflies in an ecosystem. According to Sumah \& Apriniarti (2019), human activities, such as in residential areas, tend to have low levels of butterfly diversity at these locations. This is consistent with research from Ngatimin et al. (2017), who obtained the butterfly species diversity index results in very low criteria at the Pattunuang Resort in Maros Regency. The low number of individuals found is thought to be due to longstanding poaching and the destruction of butterfly habitat due to forest conversion to agricultural land and settlements. According to Septiana et al. (2019), if land clearing is carried out continuously and converted into residential areas, it can disrupt the survival of butterflies and even experience local extinction. In line with this, previous researches (Kyerematen et al., 2014; Tam \& Bonebrake, 2016) stated that the large number of forest conversion to residential and industrial areas will result in the habitat being pressed for butterflies. Urgent habitat or low land availability from an organism will increase competition for these organisms, both competition for space (Kusumawati, 2018), competition for food, shelter and getting a partner. 
This is in accordance with the statement from Septiana et al. (2019), which stated that the diversity of butterflies was disrupted, which is due to the continuous conversion of land into residential areas.

Change of land use or land degradation can cause a decrease in the type of vegetation in an ecosystem. The fewer types of vegetation that exist in an ecosystem, the fewer types of butterflies will be found in that location (Nino, 2019). This is due to the limited food contained in the ecosystem. The more limited the availability of available food resources, the more limited the number of species and abundance of individuals an organism, one of which is butterflies, will also be limited (Rahayuningsih et al., 2012). The existence of land conversion in Indonesia, among others, can result in decreased plant species diversity which has an impact on decreasing butterfly species diversity. In line with this statement, Dewi et al. (2016) also found the diversity and abundance of individual butterflies that are low in natural ecosystems that have turned into campus areas. Mogan et al. (2018), also found the value of diversity and low abundance in locations that have been converted into plantations.

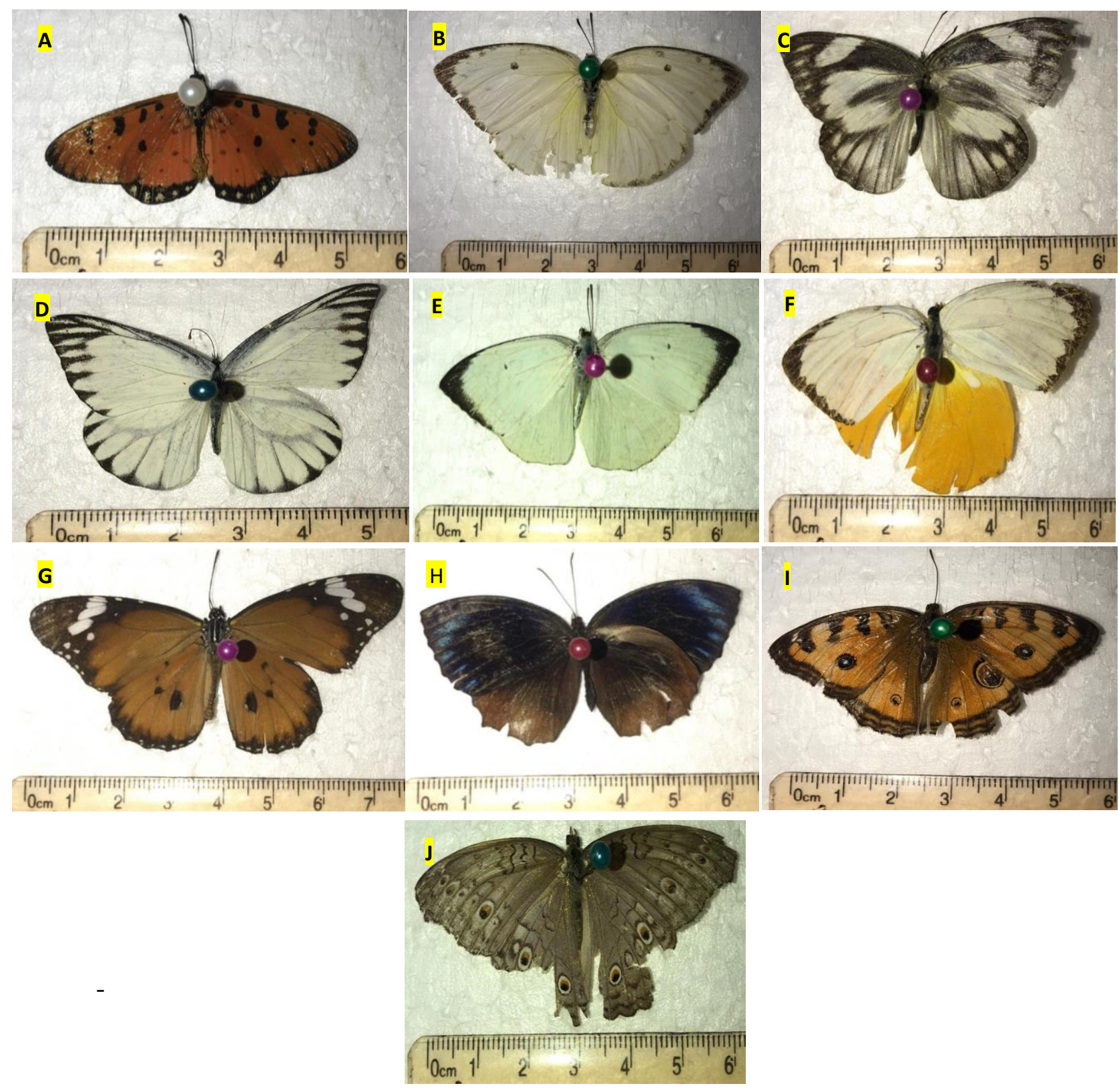

Figure 1. Butterfly species that found in the sampling areas; (A) A. violae, (B) A. statira, (C) A. libythea, (D) A. olferna, (E) C. pyranthe, (F) C. Scylla, (G) D. chrysippus, (H) E. hypermnestra, (I) J. almana and (1J) J. altites 
Table 2. Host plant and nectary plant found around campus 4 areas

\begin{tabular}{lcccc}
\hline \multicolumn{1}{c}{ Species } & Campus 4 & $\begin{array}{c}\text { Empty } \\
\text { land }\end{array}$ & Paddy field & \multicolumn{2}{c}{ Housing } \\
\hline Muntingia calabura & $\sqrt{ }$ & $\sqrt{ }$ & $\sqrt{ }$ & $\sqrt{ }$ \\
Tridax procumbens & $\sqrt{ }$ & $\sqrt{ }$ & $\sqrt{ }$ & $\sqrt{ }$ \\
Chromolaena odorata & $\sqrt{ }$ & $\sqrt{ }$ & $\sqrt{ }$ & $\sqrt{ }$ \\
Cyperus rotundus & $\sqrt{ }$ & $\sqrt{ }$ & $\sqrt{ }$ & - \\
Mangifera indica & - & - & $\sqrt{ }$ & - \\
Oryza sativa & - & - & - & - \\
Zea mays. & - & $\sqrt{ }$ & & \\
Senna alata & - & $\sqrt{ }$ & &
\end{tabular}

Note: $\sqrt{ }=$ Found; - $=$ Not found

Table 3. Butterfly species abundance found in campus 4 UAD areas

\begin{tabular}{|c|c|c|c|c|c|c|}
\hline Family & Species & Campus 4 & Empty land & Paddy field & Housing & Total \\
\hline \multirow{5}{*}{ Nymphalidae } & Acraea violae & 5 & 8 & 8 & 4 & 25 \\
\hline & Aphrissa statira & 3 & $\mathrm{O}$ & 8 & 5 & 16 \\
\hline & Danaus chrysippus & 37 & 10 & 6 & 2 & 55 \\
\hline & $\begin{array}{l}\text { Elymnias } \\
\text { hypermnestra }\end{array}$ & $\mathrm{O}$ & $\mathrm{O}$ & $\mathrm{O}$ & 4 & 4 \\
\hline & Junonia almana & O & 5 & 3 & 1 & 9 \\
\hline \multirow{5}{*}{ Pieridae } & Junonia atlites & $\mathrm{O}$ & 2 & $\mathrm{O}$ & $\mathrm{O}$ & 2 \\
\hline & Appias libythea & $\mathrm{O}$ & 1 & $\mathrm{O}$ & $\mathrm{O}$ & 1 \\
\hline & Appias olferna & $\mathrm{O}$ & 12 & 4 & $\mathrm{O}$ & 16 \\
\hline & Catopsilia pyranthe & 7 & 36 & 57 & 25 & 125 \\
\hline & Catopsilia Scylla & $\mathrm{O}$ & 2 & $\mathrm{O}$ & $\mathrm{O}$ & 2 \\
\hline \multicolumn{2}{|c|}{ Total } & 52 & 76 & 86 & 41 & \\
\hline
\end{tabular}

This study found that plants were thought to be host plants and a source of nectar from the butterflies obtained (Table 2 ).

Santosa (2017) stated that the diversity of butterflies species found was largely determined by differences in plant vegetation in an area. Dewi et al. (2016) stated that the low diversity and abundance of butterfly species, especially the Papilionidae family, around the Pinang Masak campus, Jambi University, allegedly due to the lack of variation in food sources in the area. Whereas, Mogan et al. (2018) found that the number of species found at the Sam Ratulangi University Campus was lower because it was greatly influenced by the diversity of vegetation as a host plant and a source of nectar for butterflies. This is in line with the statement from Koneri \& Saroyo (2011), that differences in the diversity index of butterfly species in a habitat are strongly influenced by the vegetation of the butterfly host plants. The variety and heterogeneity of the vegetation will affect the existence and diversity of butterflies. This is in line with Lamatoa et al. (2013), which stated that the difference in the number of butterfly species found depends on the diversity of plants as food and a host source for these butterflies.

\section{Abundance of Butterfly Species Around Campus 4 Ahmad Dahlan University}

Based on the result of the study, the highest abundance of butterfly species was $C$. pyranthe in 4 areas, while the lowest abundance was $A$. libythea (Table 3). Based on the table above, the Nymphalidae Family has the highest number of species compared to the Pieridae Family. According to Rahayu \& Basukriadi (2012), the Nymphalidae Family is a family that has the highest number of species, the widest distribution, and a variety of forage plants. Khyade et al. (2018); Nylin \& Nylin, (1988), which states that the Nymphalidae family tends to be polyphagous, that isthey have more than one type of food preference. (Mogan et al., 2018), stated that this was due to the ability to adapt to environmental conditions so that species from the Nymphalidae Family could be found at each research location. This is consistent with research by (Rahayu \& Basukriadi, 2012), who found species from the Nymphalidae family in several types of ecosystems. The large number of butterfly species from the Nymphalidae family is thought to be because around the campus area 4 there are several plants that are suitable to support the life of the Nymphalidae Family butterflies. There are a lot of plants that are a source of food for members of the 
Nymphalidae family, including those from the Annonaceae, Fabaceae, Leguminoceae and Astreracea families. This is what causes members of the Nymphalidae Family to be everywhere with a large number of species (Khyade et al., 2018).

The Simpson Dominance index value of butterflies around the campus of 4 UAD Yogyakarta was obtained at 1.00. According to (Sirait et al., 2018), the criteria for the dominance index range from $\mathrm{O}-1$, where if the dominance index value is close to $\mathrm{O}$ it shows that no species dominates, whereas if the dominance index value is close to 1 it indicates that certain species dominate at that location. The factors that can influence the presence and dominance of butterflies in an ecosystem are environmental factors (Lestari et al., 2020). Butterflies are cold-blooded (poikilothermic) animals whose activities are strongly influenced by the temperature of their environment. This research was carried out where the ambient temperature was $\pm 37^{\circ} \mathrm{C}$. Butterflies are most active at $37^{\circ} \mathrm{C}$, if the temperature is more than $37^{\circ} \mathrm{C}$, the butterflies will look for shelter. In addition to air temperature, humidity also affects the presence and dominance of butterflies in an ecosystem. The humidity needed by butterflies ranges from 49-84\%. According to (Florida et al., 2015), butterflies like habitats with high humidity because it can reduce the risk of dehydration. Butterflies are animals that are active during the day when light intensity is high, because butterflies use the sun's heat to help fly. Added by (Rahayuningsih et al., 2012), light will provide heat energy so that it raises body temperature and metabolism becomes faster. Increasing body temperature in butterfly larvae will accelerate the development and life cycle of these butterfly larvae (Rahayuningsih et al., 2012).

Butterflies can respond to environmental changes, both in terms of vegetation and in terms of pollution levels. Therefore, it is necessary to observe several environmental factors that may affect the presence of butterfly species in each ecosystem. In this research, the relationship between the parameters of the insect community with environmental parameters was analyzed by using correlation analysis Pearson. The results obtained were then tested for the correlation between abiotic factors and the abundance of butterflies using Pearson Correlation. Based on the significance of correlation Pearson's in the 4 research areas between, it was found that air temperature and light intensity had a strong correlation because the sig (2-tailed) value was $0.950>0.05$ (Table 4).
Based on the significance of correlation Pearson's in the 4 research areas between the average individual butterfly and the abiotic factor, it can be concluded that there is a negative correlation. Sharm and Joshi (2009) stated that the diversity of insect species is correlated with the structural constituents of a habitat and the diversity of vegetation forms. Another factor that may correlate with the abundance of butterfly species around the campus area 4 is the diversity of vegetation. According to Septiana et al. (2019), the distribution of butterflies is very closely related to plant vegetation. This is because the female butterfly chooses one or several types of forage plants.

\section{CONCLUSION}

It can be concluded that the diversity level of butterfly species in the area of Campus 4 UAD was low. The species of butterfly that dominated in this area was $C$. pyranthe, while the less dominant was $A$. libythea.

\section{REFERENCES}

Bahar, I., Atmowidi, T., \& Peggie, D. (2016). keanekaragaman kupu-kupu superfamili papilionoidea (Lepidoptera) di kawasan hutan pendidikan gunung Walat Sukabumi, Jawa Barat. Zoo Indonesia, 25(1), $71-$ 82.

Dewi, B., Hamidah, A., \& Siburian, J. (2016). Keanekaragaman dan kelimpahan jenis kupu-kupu (Lepidoptera; Rhopalocera) di sekitar Kampus Pinang Masak Universitas Jambi Diversity. Jurnal Biospecies, 9(2), 32-38.

Diana, P., Djamahar, R., \& Isfaeni, H. (2015). Hubungan Karakteristik Lanskap Dengan Preferensi Situs Oviposisi Kupu-Kupu Di Ruang Terbuka Hijau Kawasan Jakarta Timur. Bioma, 11(1), 22. https://doi.org/10.21009/bioma1 1(1).3

Fattorini, S. (2011). Insect extinction by urbanization: A long term study in Rome. Biological Conservation, $144(1)$, 370-375. https://doi.org/https://doi.org/10.1016/j.biocon.201 0.09 .014

Florida, M., Setyawati, T. R., \& Yanti, A. H. (2015). Inventarisasi Jenis Kupu-kupu pada Hutan Kerangas di Kawasan Cagar Alam Mandor Kabupaten Landak. Protobiont, 4(1), 260-265.

Help, C. H. R., Herman, P. M. J., \& Soetaert, K. (1998). Indices of diversity and evenness. Océanis, 24(2459), $61-87$. 
Hidayat, M. (2018). Analisis Vegetasi Dan Keanekaragaman Tumbuhan Di Kawasan Manifestasi Geotermal Ie Suum Kecamatan Mesjid Raya Kabupaten Aceh Besar. BIOTIK: Jurnal Ilmiah Biologi Teknologi Dan Kependidikan, $\quad 5(2), \quad 114$. https://doi.org/10.22373/biotik.v5i2.3019

Khyade, V. B., Gaikwad, P. M., \& Vare, P. R. (2018). Explanation of Nymphalidae Butterflies. International Academic Journal of Science and Engineering, 05(02), 87-1 10. https://doi.org/10.9756/iajse/v5i1/1810029

Koh, L. P., \& Sodhi, N. S. (2004). Importance Of Reserves, Fragments, And Parks For Butterfly Conservation In A Tropical Urban Landscape. Ecological Applications, 14(6), 1695-1708. https://doi.org/10.1890/03-5269

Koneri, R., \& Saroyo. (2011). Keanekaragaman Kupu-Kupu (Lepidoptera) pada Empat Tipe Habitat di Hutan Lindung Gunung Klabat, Sulawesi Utara. Biosfera, 28(2), 85-92. doi: 10.20884/1.mib.201 1.28.2.264

Kusumawati, D. E. (2018). Pengaruh kompetisi intraspesifik dan interspesifik terhadap pertumbuhan tanaman jagung (Zea mays) dan kacang hijau (Vigna radiata). Agroradix, 1(2), 28-33.

Kyerematen, R., Akaumoah-Boateng, A., Acquah-Lamptey, D., \& Anderson, S. (2014). Land use type affects butterfly diversity: a case study of the university of ghana, main campus , Legon. Journal of Biodiversity and Enviromental Sciences, 5(5), 205-214.

Lamatoa, D. C., Koneri, R., Siahaan, R., \& Maabuat, P. V. (2013). Populasi Kupu-Kupu (Lepidoptera ) Di Pulau Mantehage, Sulawesi Utara. Jurnal Ilmiah Sains, 13(1), 52. https://doi.org/10.35799/jis.13.1.2013.2032

Lestari, D. F., Putri, R. D. A., Ridwan, M., \& Purwaningsih, A. D. (2015). Keanekaragaman Kupu-Kupu (Insekta: Lepidoptera) di Wana Wisata Alas Bromo, BKPH Lawu Utara, Karanganyar, Jawa Tengah. Pros Sem Nas Masy Biodiv Indon, 1(6), 1284-1288. DOI://10.13057/psnmbi/mo 10604.https://doi.org/1 $0.13057 / \mathrm{psnmbi} / \mathrm{mo} 10604$

Lestari, M., Widhiono, I., \& Darsono, D. (2020). Keanekaragaman Dan Kemerataan Spesies KupuKupu (Lepidoptera: Nymphalidae) Di Hutan Cagar Alam Bantarbolang, Pemalang, Jawa Tengah. BioEksakta: Jurnal Ilmiah Biologi Unsoed, 2(1), 16. https://doi.org/10.20884/1.bioe.2020.2.1.1911

Lestari, V. C., Erawan, T. S., Melanie, M., Kasmara, H., \& Hermawan, W. (2018). Keanekaragaman Jenis Kupukupu Familia Nymphalidae dan Pieridae di Kawasan Cirengganis dan Padang Rumput Cikamal Cagar Alam Pananjung Pangandaran. Agrikultura, 29(1), 1. https://doi.org/10.24198/agrikultura.v29i1.16920

Mawazin, \& Subiakto, A. (2013). Species diversity and composition of logged over peat swamp forest in Riau. Forest Rehabilitation, 1, 59-73.

Mogan, Y., Koneri, R., \& Baideng, E. (2018).
Keanekaragaman Kupu-kupu (Lepidoptera) di Kampus Universitas Sam Ratulangi, Manado (Diversity of Butterfly (Lepidoptera) in Campus of Sam Ratulangi University, Manado). Jurnal Bios Logos, 8(2), 59. https://doi.org/10.35799/jbl.8.2.2018.23357

Ngatimin, S. N. A., Abdullah, T., Nasruddin, A., \& Gassa, A. (2017). Pengenalan Jenis Kupu-kupu pada Murid SD 129 INPRES Kecamatan Bantimurung, Kabupaten Maros Sulawesi Selatan. Jurnal Hutan Dan Masyarakat, $9(1), \quad 30$. https://doi.org/10.24259/jhm.v9i1.1975

Nino, M. M. (2019) Keanekaragaman Kupu-Kupu (Lepidoptera) di Sekitar Pinggiran Sungai Maslete Kabupaten Timor Tengah Utara. Bio-Edu, 4(2), 50-58. https://doi.org/10.32938/jbe.v4i2.386.

Nylin, S., \& Nylin, S. (1988). Host Plant Specialization and Seasonality in a Polyphagous Butterfly, Polygonia CAlbum (Nymphalidae). Oikos, 53(3), 381. https://doi.org/10.2307/3565539

Pewista, I., \& Hartini, R. (2013). Faktor dan Pengaruh Alih Fungsi Lahan Pertanian Terhadap Kondisi Sosial Ekonomi Penduduk di Kabupaten Bantul. Kasus Daerah Perkotaan, Pinggiran dan Pedesaan Tahun 2001-2010. Jurnal Bumi Indonesia, 2(2), 96-103. Rahayu, S. E., \& Basukriadi, A. (2012). Kelimpahan dan Keanekaragaman Spesies Kupu-Kupu (Lepidoptera; Rhopalocera) Pada Berbagai Tipe Habitat di Hutan Kota Muhammad Sabki Kota Jambi. Jurnal Biospecies, 5(2), 40-48

Rahayu, S. E., \& Basukriadi, A. (2012). Kelimpahan dan Keanekaragaman Spesies Kupu-Kupu (Lepidoptera; Rhopalocera) Pada Berbagai Tipe Habitat di Hutan Kota Muhammad Sabki Kota Jambi. Jurnal Biospecies, 5(2), 40-48.

Rahayuningsih, M., Oqta, R., Priyono, B., Biologi, J., Matematika, F., Alam, P., \& Semarang, U. N. (2012). Keanekaragaman Jenis Kupu-Kupu Superfamili Papilionoidae Di Dukuh Banyuwindu Desa Limbangan Kecamatan Limbangan Kabupaten Kendal. Jurnal MIPA Unnes, 35(1), 115160.

Resasco, J. (2009). Butterfly Field Guide. Santa Monica: Santa Monica Mountains National Recreataion Area National Park Service.

Ruslan, H., Tobing, I. S. \& Andayaningsih, D. (2020). Biodiversitas Kири-Kири (Lepidoptera: Papilionoidea) Di Kawasan Hutan Kota Jakarta. Jakarta: LPUUNAS.

Saharjo, B. H., \& Gago, C. (2011). Suksesi Alami Paska Kebakaran pada Hutan Sekunder di Desa Fatuquero, Kecamatan Railaco, Kabupaten Ermera-Timor Leste. 4045. Retrieved from https://202.124.205.241/handle/123456789/54463 Santosa, Y. (2017). Keanekaragaman kupu-kupu di berbagai tipe 
tutupan lahan perkebunan kelapa sawit PTPN V Tamora, Kampar, Riau. $\quad 3, \quad 110-116$. https://doi.org/10.13057/psnmbi/mo30119

Sea, N., Sutra, M., \& Salmah, S. (2006). Spesies Кири-Кири ( Rhopalocera) Di Tanjung Balai Karimun Kabupaten Karimun , Kepulauan Riau Species of butterflies ( Rhopalocera ) in Tanjung Balai Karimun, Karimun Regency, Riau Archipelago. 1(1), 35-44.

Septiana, S., Yulisah, T., \& Samitra, D. (2019). Kelimpahan Dan Keanekaragaman Kupu-Kupu Di Kecamatan Tugumulyo Kabupaten Musi Rawas. Pro-Life, 6(1), 55. https://doi.org/10.33541/pro-life.v6i1.939

Setiawan, R., Wimbaningrum, R., \& Fatimah, S. (2018). Keanekaragaman Jenis Kupu-Kupu (Lepidoptera: Rhopalocera) di Zona Rehabilitasi Blok Curah Malang Resort Wonoasri Taman Nasional Meru Betiri. Natural Science: Journal of Science and Technology, 7(2), 252-258. Septiana, S., Yulisah, T., \& Samitra, D. (2019). Kelimpahan Dan Keanekaragaman Kupu-Kupu Di Kecamatan Tugumulyo Kabupaten Musi Rawas. Pro-Life, 6(1), 55. https://doi.org/10.33541/prolife.v6i1.939

Sirait, M., Rahmatia, F., \& Pattulloh, P. (2018). Komparasi Indeks Keanekaragaman Dan Indeks Dominansi Fitoplankton Di Sungai Ciliwung Jakarta (Comparison Of Diversity Index And Dominant Index of Phytoplankton At Ciliwung River Jakarta). Jurnal Kelautan: Indonesian Journal of Marine Science and Technology, 11(1), 75 . https://doi.org/10.21107/jk.v11i1.3338

Sumah, A. S. W., \& Apriniarti, M. S. (2019). Kupu-Kupu Papilionidae (Lepidoptera) Di Kawasan Cifor, Bogor, Indonesia. Jurnal Biologi Tropis, 19(2), 197. https://doi.org/10.29303/jbt.v 19i2.1309

Susilawati. (2010). Keragaman Lepidoptera pada Dukuh dan Kebun Karet di Desa Mandiangin Kabupaten Banjar. Jurnal Hutan Tropis, 1 1(29), 18-23.

Tam, K. C., \& Bonebrake, T. C. (2016). Butterfly diversity, habitat and vegetation usage in Hong Kong urban parks. Urban Ecosystems, 19(2), 721-733. https://doi.org/10.1007/s1 1252-0 15-0484-2

Thom, D., \& Seidl, R. (2016). Natural disturbance impacts on ecosystem services and biodiversity in temperate and boreal forests. Biological Reviews of the Cambridge Philosophical Society, 91(3), 760-781. https://doi.org/10.1111/brv.12193

Triyogo, A., Anshorulloh, A. J., \& Widyastuti, S. M. (2016). Populasi Serangga pada Tingkat Perkembangan Agroforestri Jati yang Berbeda Insect Populations at Different Stages of Teak Based-Agroforestry System Pendahuluan Metode Penelitian. Jurnal Biota, I(April), 75-84. 